\title{
Therapeutic Potentials of Bioactive Compounds of Azadiracta Indica ( Neem) to Treat Ailments of Humanbeing
}

\author{
Dr. Ch. Srinivasa Prasadacharyulu \\ Associate Professor of Biochemistry P.V.K.N.Govt.College, Chittoor Andhra Pradesh, India
}

\begin{abstract}
Azadiracta indica (Neem) native of India has uncountable medicinal properties of variousbioactive compounds which are present in the roots to seeds of this plant.Biologically active compounds namely Azadirachtin, meliacin, , Meliantriol ,Nimbin, Nimbidin, Salannin, Salannol vilasinin,are isolated from different parts of Neem plant .Biologically more active compound is azadirachtin, a tetranotriterpenoid is isolated from the seeds of Neem which is actually a mixture of seven isomeric compounds named as azadirachtin A-G and azadirachtin $\mathrm{E}$ is the most effective one. Two bioactive compounds azadirachtin $\mathrm{M}$ and azadirachtin $\mathrm{N}$ collected from seed kernels of Azadirachta indica,these two compounds hasa major role in medicinal activities. The bioactive compound "Azadiachtin" has antimalarial, antigingivitis and antiplaque properties and also has antibacterial action by destroying the bacterial cells. The bioactive compound Nimbidin has anti- inflammatory antipyretic, antiarthritic, hypoglycemic , anti- gastric ulcer, antibacterial and antifungalproperties.Nimbin exhibits spermicidal function. The neem oil was extracted from neem kernels. This oil used in soap industry and by pharmaceutical industries and contain many active ingredients which are called triterpene or limonoids .Neem oil showed good antiseptic properties. It is applied in the treatment of skin complaints as furuncles and eczema.Therapeutical potentials of neem is due to the presence of various Bioactive compounds in roots to seeds of its body.
\end{abstract}

Key Words: (1). Azadiracta indica (2). Bioactive compounds (3). Azadiractin,(4). Nimbin, (5). Nimbidin etc., (6). Antimalarial, anti inflammatory and antiarthritic etc.,

\section{INTRODUCTION}

Azadirachta indica (A. Juss.) Neem is native of India, very ancient medicinal plant and it has unique therapeutic potentials to treat multifactorial diseases of humanbeing . Neem is called "Arista" in Sanskrit that means perfect, complete and imperishable and reliver of sickness(13). The first medicinal plant mentioned in the Siddha medical system is neem (35). The importance of Neem tree has been recognised by the US National Academy of Sciences, which publish a report in 1992 entitled " The neem tree is an incredible plant that has been declared the "Tree of the 21 st century" by the United Nations.(40).

A perusal of literature studies on Ara et al.,1989; Bannerman,1982; Botelho et al., 2008; Brahmachari, 2004 ; Debashri and Tamal ,2012; Hedge,1995; Kakai and Koha,1984; Khare,2007; Morgan,2009; Murthy and Sirsi 1958; Ngure et al.,2013; Pandey et al.,2012; Pankaj et al., 2011; Pillai and Santhakumari,1981; Puri,1999; Sudhir et al., 2010 ; Uko and Kamalu,2001revealed that all the body parts of Azadiracta indica has potential medicinal bioactive compounds which are involved in various medical fields to cure diseases of human being and also play an important role in plant protection and environment.

\section{MATERIAL AND METHODS}

Neem's leaves, seeds, bark, roots, fruits and oil have become a cynosure of modern medicine and used medicinally for treatment various diseases specially in Indian Ayurvedic medicine, Homoeopathic medicine Homoeopathic medicine and Unani (37). 
Dr. Ch. Srinivasa Prasadacharyulu , International Journal of Ayurvedic \& Herbal Medicine 9(3) May.-June. 2019 (3514-3520) The structure of chemical compounds of Azadirachta indica is complex. Biologically active compounds isolated from different parts of Neem plant include Azadirachtin, meliacin, Nimbin, valasinin, Nimbidol(17). Therefore, many years of study and research were done to elucidate the exact structure of azadirachtin. In 1968 Azadirachtin was first isolated by Butterworth and Morgan (7). Since that, more than 100 related compounds had been isolated from the neem tree, and these could be assigned to one of three groups: azadirachtols, azadirachtins, and meliacarpins (Figure 1. 38 and 41).

Biologically more active compound is azadirachtin, a tetranotriterpenoid is isolated from the seeds of Neem which is actually a mixture of seven isomeric compounds named as azadirachtin A-G and azadirachtin $\mathrm{E}$ is the most effective one (42). Azadirachtin belongs to the C-seco limonoids which was classified as tetranotriterpenes (22). Two novel compounds of azadirachtin analogues collected from seed kernels of Azadirachtaindica: labelled as azadirachtin $\mathrm{M}$ and azadirachtin N (Figure 2 . ) (23 and 9 ).

Azadirachtin M (1) was identified as 29-oxymethylene-11-demetoxycarbonyl-11 $\alpha$ -

hydroxyazadirachtin(Figure: 2, 23 and 9).

Azadirachtin N (2) was identified as 22,23-dihydro-23 $\alpha$-hydroxy-3-tigloyl-11deoxyazadirachtinin (Figure: 2,23 and 9 ).

These two compounds is more effective and play major role in medicinal activities (42).

Azadiachtin" has antigingivitis and antiplaque properties and also has antibacterial action by destroying the bacterial cell wall and inhibiting the growth of bacteria via the breakdown of cell wall disturbing the osmotic pressure which leads to cell death (8).

Around $30-50 \%$ of the neem oil was extracted from neem kernels. This oil used in soap industry and by pharmaceutical industries and contain many active ingredients which are together called triterpene or limonoids (11). The four best limonoids compounds were included Azadirachtin, Salannin, Meliantriol, and Nimbin. (Figure 3) (15 and 20 ).

Neem oil has antiseptic properties. It is applied in the treatment of such skin complaints as furuncles and eczema, as well as to relieve intestinal worm infections (12). The leaves of the neem tree are also used as natural treatment for acne sufferers (3). Neem Commercially available as: Mouth washes ( 8), Neem oils , Soaps , Creams and Shampoo (44). Meliacin is the bitter active compound of neem seed oil and for the distinctive odor of the oil tignic acid (5-methyl-2-butanic acid) is responsible [33 and 21).

\section{RESULT AND DISCUSSION \\ RESULT}

Azadiractaindica (Neem) has been extensively used in India as an Ayurvedic medicine for the treatment of various human ailments such as dental diseases to cancer.

The important Bioactive compounds of Azadiractaindica namely azadirachtinazadirachtin $\mathrm{M}$ and azadirachtinN, Nimbin, Salannin,SalannolAzadiractin, Meliantriol , Nimbidin,Meliacin and Vilasinnin are isolated and chemically synthesized respectively (FIG:2, 3, 4 and 5 ).

Biologically more active compound is azadirachtin, a tetranotriterpenoid is isolated from the seeds of Neem which is actually a mixture of seven isomeric compounds named as azadirachtin A-G and azadirachtin E is the most effective one (42).Azadiachtin" has antigingivitis and antiplaque properties and also has antibacterial action by destroying the bacterial cell wall and inhibiting the growth of bacteria via the breakdown of cell wall disturbing the osmotic pressure which leads to cell death (8). The Bioactive compound of neem namely Gedunun gave significant control as effective as quinine on malaria.The mechanism is that redox status of RBCon parasite. The plasmodial parasite generats oxidant, while neem extracts reduced the oxidized cells to destroy the malarial parasite.

Vitiligo is an autoimmune disorder that causes patches of skin to lose its colour.Neem oil applied to the affected area could aid in the reversal of discoloration. One gram of capsule of paste of neem leaves oral medication once in a day before meal. Low dose of neem leaves extract have sedative effect. It also reduses 
Dr. Ch. Srinivasa Prasadacharyulu , International Journal of Ayurvedic \& Herbal Medicine 9(3) May.-June. 2019 (3514-3520) anxiety and stress. Antiviral efficacy of neem leaves against small- pox and chicken- pox ect . Hence, in India neem leaves is used to treat viral diseases such as smallpox, chicken-pox. Neem leaf extract has a power to supress polio viruses. The leaves of the neem tree are also used as natural treatment for acne sufferers (3).Neem leaf powder could be used asbiosorbent for the removal of dyes like congo red from water.

Neem barks and leaves posses antiseptic property, hence use as active ingredient in tooth paste in India and Germany. The neem seed oil [NSO] and leaf extracts act as powerful spermicide and inhibited spermatogenesis, decreased sperm motility, count and cessation of fertility. These conditions were reversed by the withdrawal of neem products 4-6 weeks later. Hence, neem formulation "Sensal" use in India as powerful contraceptive. Inflammatory stomatitis in children is cured by the bark extract of neem.

Neem oil was extracted from neem kernels. This oil used in soap industry and by pharmaceutical industries and contain many active ingredients which are together called triterpene or limonoids (11). Neem oil showed good antiseptic properties. It is applied in the treatment of such skin complaints as furuncles and eczema (12).Neem Commercially available as: Mouth washes ( 8), Neem oils, Soaps, Creams and Shampoo (44).

\section{DISCUSSION}

Table-1 Indicates that the classification of Azadiractaindica( Neem). Table-2 Reveals that Azadiractin has antimalarial property. Nimbidin has Anti-inflammatory, Antipyretic, Antiarthritic, Hypoglycemic, Antigastric ulcer, Antibacterial and Antifungal properties. Nimbin has spemicidal property.Table -3 Shows medicinal uses of various parts of neem to treat different diseases of humanbeing.

Figure: 1. Explains Various Bioactive compounds had been isolated from the neem tree, and these could be assigned to one of three groups: azadirachtols, azadirachtins, and meliacarpins.

Figure:2. Exhibits Two novel compounds of azadirachtin analogues collected from seed kernels of Azadirachtaindica: labelled as azadirachtin $\mathrm{M}$ and azadirachtin $\mathrm{N}$.

Figure: 3,figure 4 and figure 5 shows that the important Bioactive compounds of Azadiractaindica namely Nimbin, Salannin,Salannol(Fig.3),Azadiractin, Meliantriol, Nimbidin (Fig. 4), Meliacin and Vilasinnin (Fig. 5)are isolated and chemically synthesizedrespectively.Therapeutical potentials of neem is due to the presence of various Bioactive compounds in roots to seeds of its body.

Neem has high rate of photosynthesis and liberats more oxygen than many other tree species, thus purifying the atmosphere.Neem products have water purifyimg activity. The temperature under the neem tree has been found to be -10 degree centigrade less than the surround temperature during hot summer months. In agroforesty, neem products benefits extended to providing shade, firewood, timber etc. The large scale plantation of neem trees help to combat desertification, deforestation, soil erosion and reduce excessive global warming.

\section{FIGURES AND TABLES FIGURES}

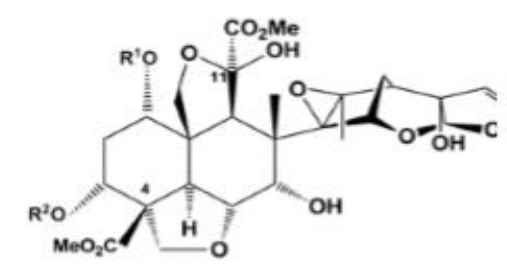

Azadirachtin Group

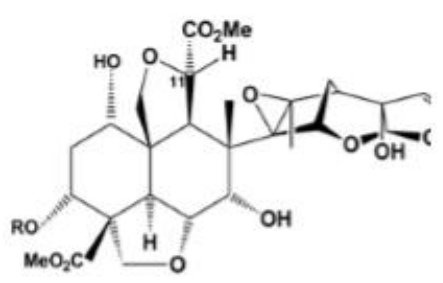

Azadirachtol group

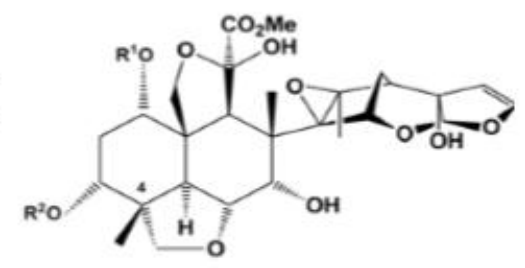

Meliacarpin group

Figure (1).(38and 41). 
Dr. Ch. Srinivasa Prasadacharyulu , International Journal of Ayurvedic \& Herbal Medicine 9(3) May.-June. 2019 (3514-3520)

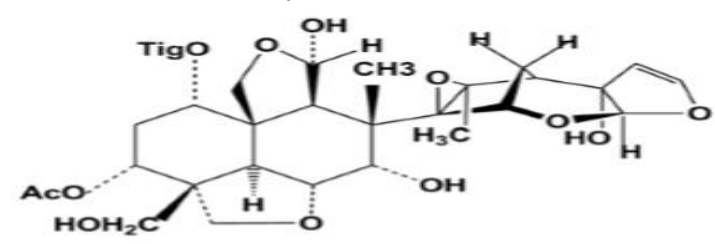

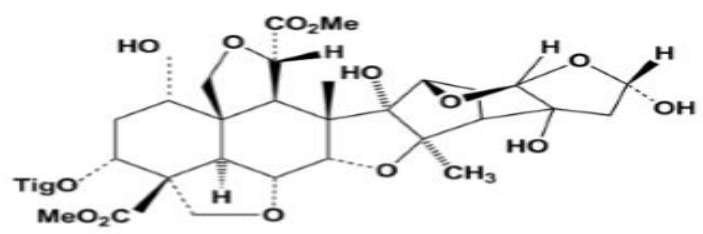

Figure(2): Two novel compounds of azadirachtin analogues collected from seed kernels Of Azadirachta indica ( 23 and 9)

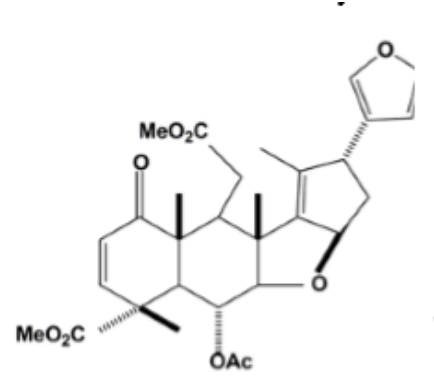

Nimbin

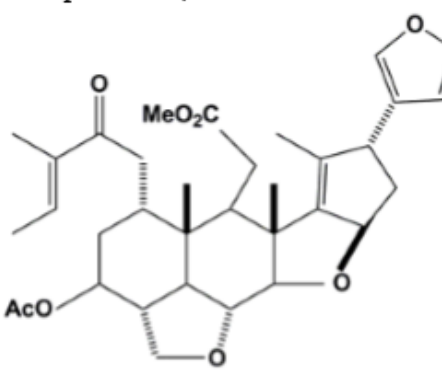

Salannin

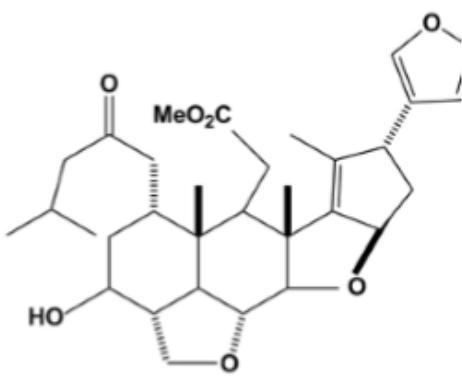

Salannol

Figure(3): Some of the limonoid compounds isolated from Azadirachta indica. (ChemDraw Ultra

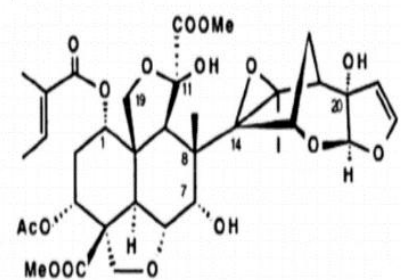

azadirachtin

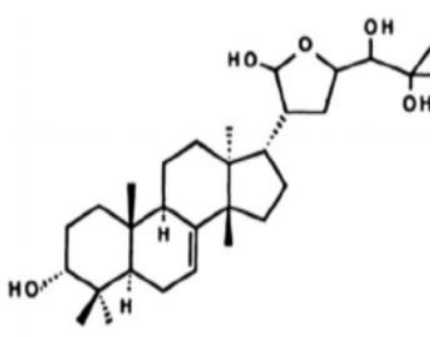

meliantriol

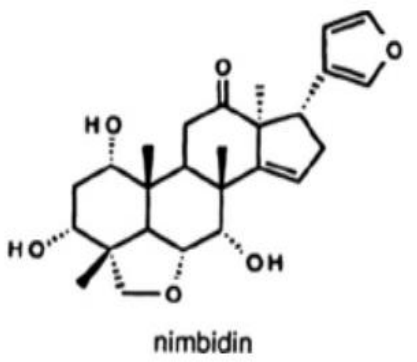

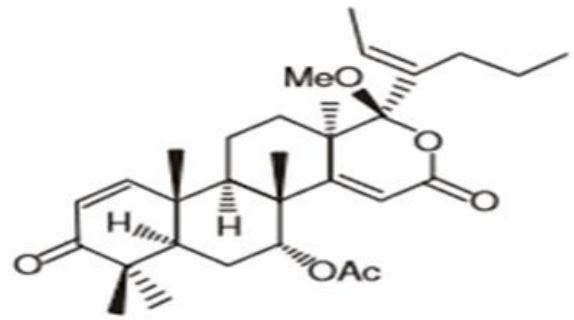

Figure4 . Bioactive compounds of Azadiracta indica( 31.)

Meliacin<smiles>C[C@@]12C3=CC[C@@H](c4ccoc4)[C@@]3(C)[C@H](O)[C@H]1OC[C@@]1(C)[C@H]2CC[C@H]1O</smiles>

\section{MELIACIN (32)VILASINNIN(34)}

Figure 5. Bioactive compounds of Azadiracta indica ( 32 and 34) 


\section{TABLES}

\section{Classification of Neem plant (13).}

\section{TABLE: 1}

Kingdom Plantae

Phylum : Vascular plant

Class Magnoliopsida

Order : Rutales

Family : Meliaceae

Genus : Azadirachta

Species : Indica

TABLE 2. Some Bioactive compunds of Neem and their biological activity (13)

\begin{tabular}{|l|l|l|l|}
\hline S. no. & Bioactive compound of Neem & Source & Biological Activity \\
\hline 1 & Azadirachtin & Seed & Anti malarial \\
\hline 2 & Nimbidin & Seed oil & $\begin{array}{l}\text { Anti- inflammatory ,Antipyretic , } \\
\text { Antiarthritic, Hypoglycemic, Anti gastric } \\
\text { ulcer,Antibacterial, and Antifungal }\end{array}$ \\
\hline 3 & Nimbin & Seed oil & Spermicidal \\
\hline
\end{tabular}

\section{TABLE: 3. Medicinal Uses Of Neem [ Azadiracra Indica] (4).}

\section{Parts Of Neemmedicinal Uses}
(1). Bark : Analgesic, alternative and curative of fever .
(2). Flower : Bile suppression, elimination of intestinal worms and phlegm .
(3).Seed pulp : Intestinal worms and leprosy.
(4). Fruit : Relieves piles, intestinal worms, epistaxis, urinary disorder, eye problem, phlegm, diabetes, wounds and leprosy.
(5). Leaf : Eye problem, leprosy, intestinal worms, epistaxis, anorexia, skin ulcers,Biliousness
(6). Oil : Intestinal worms and leprosy.

(7).Gum: Effective against skin diseases like ring - Worms, scabies, wounds and ulcers.

(8).Twig:Relieves cough, piles, phantom tumor, asthma, spermatorrhea, intestinal Worms, diabetes, urinary disorder.

(9). Root, bark, leaf ,flower ,fruit : Blood morbidity, itching, burning sensation

Skin ulcers and Leprosy.

Neem-based products from Azadirachta indica are traditionally used for pest control in agriculture and gardening since long in India (14 and 43).

\section{REFERENCES}

1. Ara I, siddiqui B S, faizi S, and sidddiqui S. structurally novel diterpenoid constituents from the stem bark of Azadirachta indica(melieceae). J. chem soc perkin trans 1989; 2,343-345.

2. Bannerman RH. Traditional medicine in modern health care. World Health Forum 1982; 3(1): 8-13.

3. Bhowmik D, Yadav J, Tripathi K, Kumar KS. Herbal remedies of Azadirachta indica and its medicinal application. J. Chem Pharm Res 2010;2(1):62-72. 
Dr. Ch. Srinivasa Prasadacharyulu , International Journal of Ayurvedic \& Herbal Medicine 9(3) May.-June. 2019 (3514-3520)

4. Biswas K, Chattopadhyay I, Banerjee RK, Bandyopadhyay U. Biological activities and medicinal properties of neem (Azadirachta indica). Curr Sci 2002;82(11):1336-45.

5. Sharma V N, Saksena K P, ,Sodium nimbidinate-in vitro study of its spermicidal action .Indian journal [34] Rachanakij S, Thebtarananth Y, Yenjal C H and Yuthavong Y, nimbolide a constitute of Azadirachtaindicainhibits Plasmodium falciparum in culture southeast Asian $\mathrm{j}$ trop med public health 1985, 16, 6ORDERED REFERENES FINAL TO PULISHORDERED FINAL REFERENCE

6. Botelho MA, Santos RA, Martins JG, Carvalho CO, Paz MC, Azenha C et al. Efficacy of a mouth rinse based on leaves of the neem tree (Azadirachtaindica) in the treatment of patients with chronic gingivitis: A double blind, randomized, controlled trial. J Med Plant Res 2008;2(11):341-346.

7. Brahmachari G. Neen-An omnipotentplant: a retrospection.Chembiochem 2004;5(4):408-21.

8. Butterworth $\mathrm{JH}$, Morgan E. Isolation of a substance that suppresses feeding in locusts. Chem Commun 1968 ; (1):23-4.

9. Chatterjee A, Saluja M, Singh N, Kandwal A. To evaluate the antigingivitis and antipalque effect of an Azadirachta indica (neem) mouthrinse on plaque induced gingivitis: A double-blind, randomized, controlled trial. J Indian Soc Periodontol 2011;15 (4):398-401.Chem draw Ultra12.0

10. Debashri M, Tamal MA. Review on efficacy of Azadirachta indica A. Juss based biopesticides An Indian perspective.Res J Recent Sci 2012;1(3):94-9.

11. Djenontin Tindo S, Amusant N, Dangou J, Wotto D, Avlessi F, DahouénonAhoussi E et al. Screening of Repellent, Termiticidal and Preventive activities on Wood, of Azadirachta indica and Carapa procera (Meliaceae) seeds oils. ISCA J Biological Sci 2012;1(3):25-9.

12. Forster P, Moser G. Status report on global neem usage: Deutsche Gesellschaft für Technische Zusammenarbeit (GTZ). Eschborn Germany 2000; p 122.

13. Girish K, Shankara Bhat S. Neem-a green treasure. Electron J Biotechnol 2008;4(3):201-111.

14. Habluetzel A, Lucantoni L, Esposito F. Azadirachta indica as a public health tool for the control of malaria \& other vector-borne diseases. Indian J Med Res 2009;130(2):112-4.

15. Hashmat I, Azad H, Ahmed A. Neem (Azadirachta indica A. Juss)-A nature's drugstore: an overview Int Res J Biol Sci 2012;1(6):76-9.

16. Hedge N G. Neem and small farmers constraints at grass root level. Indian Forester 1995;121 (11):1040-8.

17. Kabeh J D, and Jalingo M G D S S .Exploiting Neem( Azadiracta indca) Resource for Improving the Quality of Life in Taraba State , Nigeria. International Journal ofAgriculture and Biology 2007; 9 (3) :530-532.

18. Kakai T, Koha J P. anti-inflammatory polysaccharides from Melia Azadirachta . chem Abstr 1984;100,913-50.

19. Khare CP. Indian medicinal plants: an illustrated dictionary. Springer, 2007.

20. Klocke J. Plant compounds as source and models of insect-control agents research Eamp.Editor, Academic Press, London, 1989, 103-44.

21. Lale N E. Bio-activity and limitation against wide spread use of neem products for the management of insect pests. Niger J Appl Biol 2002;3 (1):115-24.

22. Ley S V. Development of methods suitable for natural product synthesis: The azadirachtin story. Pure Appl Chem 2005; 77(7):1115-30.

23. Luo X, Ma Y, Wu S, Wu D. Two novel azadirachtin derivatives from Azadirachta indica. J Nat Prod 1999;62(7):1022-4.

24. Morgan ED. Azadirachtin, a scientific gold mine. Bioorg Med Chem 2009;17(12): 4096-105. 10

25. Murthy S P, and Sirsi M 1958. Pharmacological studies on melia Azadirachta indica. Indian journal of physicology and pharmacology 1958; 2, 387-396. 
Dr. Ch. Srinivasa Prasadacharyulu , International Journal of Ayurvedic \& Herbal Medicine 9(3) May.-June. 2019 (3514-3520)

26. Ngure RM, Ongeri B, Karori SM, Wachira W, Maathai RG, Kibugi J et al. Anti-trypanosomal effects of Azadiracta indica (neem) extract on Trypanosoma brucei rhodesiense-infected mice. Eastern J Med 2013;14(1):2-9.

27. Pandey IP, Ahmed SF, Chhimwal S, Pandey S. Chemical Composition and Wound healing activity of Volatile oil of Leaves of Azadirachta indica A. juss. Adv Pure Appl Chem 2012;1(3):62-6.

28. Pankaj S, Lokeshwar T, Mukesh B, Vishnu B. Review on neem (Azadirachta indica):Thousand problems one solution. IRJP 2011;2(12):97-102.

29. Pillai N R and Santhakumari G. antiarthritic and anti-inflammatory actions of nimbidin planta medics 1981;43,59-63.

30. Puri HS. Azadirachta indica. Amsterdam. Harwood Academic Publishers; 1999. Neem: The divine tree; pp. 1-3.

31. Sanjay k Sharma, Anjali Peter and Ime Bassey Obot. Potential of Azadiracta indica as a Green corrosion inhibitor against mild steel, aluminium and tin: a review. Journal of Analytical science and technology 2015; 6: 26.

32. Sathish Kumar A S, Kotte Subhash Chandra Bose, Pavan Kumar K V T S, Shri Ram Ragahvan and Murali P. Terpenoids and its commercial Utility from Neem The Nature's Own Pharmacy. Asian journal of Chemistry 2014; 26(16): 4940-4948.

33. Schmutterer H. Properties and potential of natural pesticides from the neem tree, Azadirachta indica. Annu Rev Entomol 1990 ; 35:271-97.

34. Shradha M.Patel, Kalyan c, Nagulapalli Venkata, Piyali Bhattacharyya, Gautam Sthi and Anupam Bishayee. Potential of neem( Azadiracta indica L.) for prevention and treatment of Oncologic diseases. Seminars in Cancer Biology 2016 VOL.40-41, PAGES 100-115.

35. ( 35). Subbarayappa BV. Siddha medicine: an overview. Lancet 1997;350(9094):18411844. [PubMed

36. P. Sudhir Kumar, Debasis Mishra, Goutam Ghosh and Chandra S Panda. Biological action and medicinal properties of various constituent of Azadirachta indica (Meliaceae) an Overview. Annals of Biological Research 2010;1 (3) :24-34.

37. Tiwari R, Verma AK, Chakraborty S, Dhama K, Singh SV. Neem (Azadirachta indica) and its potential for safeguarding health of animals and humans: A review. J Biol Sci 2014;14(2):110-23.

38. Turner CJ, Tempesta MS, Taylor RB, Zagorski MG, Termini JS, Schroeder DR et al. An NMR spectroscopic study of azadirachtin and its trimethyl ether. Tetrahedron 1987;43(12):2789-803.

39. Uko OJ, Kamalu TN. The neem tree-uses and potentials. Niger J Exp Appl Biol 2001; 2 (2):223-9. United Nations Environment Programme Neem. 2012.

40. Veitch GE, Pinto A, Boyer A, Beckmann E, Anderson JC, Ley SV. Synthesis of natural products from the Indian neem tree Azadirachta indica. Org Lett 2008;10(4):569-72.

41. Verkerk R H, Wright DJ. Biological activity of neem seed kernel extract and synthetic azadirachtin against larvae of Plutella xylostellal. Pestic Sci 1993;37 (1):83-91

42. Vietmeyer ND. Neem: a tree for solving global problems. Report of an adhoc panel of the Board on Science and Technology for International Development.1992.

43. Warra A A. Medicinal and cosmetic potential of neem (Azadiracta indica) seed oil: A review. Res Rev J Med Chem 2012;1 (1):5-8. 